\title{
Online Games for Primary School Vocabulary Teaching and Learning: A Literature Review
}

\author{
Syafiqah Hasram, Fatin Kamilia Mohd Arif, M. Khalid M. Nasir*, Maslawati Mohamad*, \\ Md. Yusoff Daud, Mohd Jasmy Abd Rahman, Wan Muna Ruzanna Wan Mohammad \\ Universiti Kebangsaan Malaysia (UKM), Bandar Baru Bangi, Selangor, Malaysia \\ Email: syafiqahasram@gmail.com, ^maslawati@ukm.edu.my, *mdkhalid@ukm.edu.my
}

How to cite this paper: Hasram, S., Arif, F. K. M., Nasir, M. K. M., Mohamad, M., Daud, Md. Y., Rahman, M. J. A., \& Mohammad, W. M. R. W. (2020). Online Games for Primary School Vocabulary Teaching and Learning: A Literature Review. Creative Education, 11, 2327-2336.

https://doi.org/10.4236/ce.2020.1111170

Received: October 17, 2020

Accepted: November 15, 2020

Published: November 18, 2020

Copyright $\odot 2020$ by author(s) and Scientific Research Publishing Inc. This work is licensed under the Creative Commons Attribution International License (CC BY 4.0).

http://creativecommons.org/licenses/by/4.0/

(c) (i) Open Access

\begin{abstract}
Vocabulary knowledge in second language learning is imperative in acquiring competence and mastery in the language. It is a fundamental competence that English Second Language (ESL) learners need to master as a wide vocabulary repertoire is necessary in aiding them to understand verbal and written communication. This literature review also highlights that Malaysian undergraduates' learners are lacking in vocabulary mastery that caused drastic decline in their proficiency of both written and spoken English. The integration of educational online games in teaching vocabulary has a growing popularity due to the widespread belief on its potential to enrich learning process. This paper provides a literature review on the elements, interest, and challenges of the online games in ESL learners based on multiple past studies. It is proven in the literature that online games are potential tools in vocabulary learning as it raises learners' learning satisfaction, and fosters autonomous learning among learners. Many studies have also proven that online games support the acquisition of $21^{\text {st }}$ century skills. Nevertheless, in the eagerness to employ online games, it is imperative for educators to be aware of the challenges before making a wise decision to integrate online games as classroom activities.
\end{abstract}

\section{Keywords}

Vocabulary, Online Games, ESL Learners, Teaching and Learning

\section{Introduction}

Most Malaysians use English as a Second Language (ESL) or a foreign language. However, many Malaysian learners are reported to have limited number of English language vocabulary repertoires which contribute to their low proficiency level (D'Silva, 2019). This is supported by the findings of several past studies 
which reported that Malaysian undergraduates are lacking in vocabulary mastery despite the compulsory English learning throughout primary and secondary school years. Majority of them failed to possess even the minimum word level (2000 words) out of five word-levels (Lateh et al., 2018). Wang and Yamat (2019)'s findings on local Year Five participants (11 years old), indicate that many primary pupils throughout Malaysia have low vocabulary repertoire. In other words, they are yet to achieve the standard set by the Malaysia Standard-Based Curriculum English Syllabus.

Their limited vocabulary repertoire is due to lack of interest in learning vocabulary when they are taught using the traditional method (Alqahtani, 2016; Ting \& Kee, 2019). Thus, capturing pupils' interest and motivating them are important in the vocabulary learning process. When they stop enjoying lessons, there is a tendency for them to learn less in class (Nasir, Surat, Maat, Abd Karim, \& Daud, 2018; Nasir, Mansor, \& Rahman, 2018). Afzal (2019) also found that the majority of teachers still employ the traditional teaching methods which are outdated. Mohammad et al.'s findings (2018) indicate that many of the teacher-centered strategies are irrelevant to learners of today generation as they are heavily dependent on memorizing unfamiliar words with their definitions (Derakhshan \& Khatir, 2015) and paired translations (Nejati et al., 2018). These learners who are also known as the digital natives, are more fluent in the usage of technology and there is a growing demand of gamified teaching and learning in education (Chapman \& Rich, 2018; Kessler, 2018).

Managing digital natives require conducive environment and educators who are capable of using technology to engage learners in technology-based activities (Hamari \& Sarsa, 2014; Nasir et al., 2018; Nasir, Mansor, \& Rahman, 2018). For instance, formulating online games to scaffold and motivate students in learning vocabulary is not an essay job (Zainuddin et al., 2020). Thus, the researchers attempt to discuss the following aspects of online learning in this article. The aspects are elements, benefits, and challenges of integrating online games in language learning. By doing so, teachers could make a wiser decision in integrating the online games in their own classroom context.

\section{Elements and Benefits of Online Games}

In a digitally advanced world, the idea of a gamified learning has been constantly discussed among stakeholders in education. Figueroa-Flores (2015) mentioned that the adjustment of more technology-oriented teaching strategies is in accordance to the needs of the new generation of learners, the digital natives. There is a strong relation between emergent technologies and gamification in learning, which offers abundant of potentials in education. Gamification is the process of using games elements to enhance traditionally non-gaming environments (Deterding et al., 2011; Talib et al., 2016). In education, online games integrate games thinking and games mechanics to solve problems and engage audiences in interactive learning (Takahashi, 2010; Bakhsh, 2016; Chapman \& Rich, 2018). 
The fundamental elements of an online game are interesting multimedia with customized text, graphic, audio and animation. These games elements are designed to express ideas and information in a more creative and fun way. The pivotal aims are to attract and sustain learners' attention (Talib et al., 2016). Ashraf et al. (2014) highlight that engaging learners in online games could create space for comprehensive vocabulary instruction. Online games often incorporate elements which motivate and engage learners in the classroom; such as points-and-rewards system, immediate feedback (Darejeh \& Salim (2016), levels and leaderboard (Mohamad et al., 2020) as well as challenges and sense of engagement (Abrams \& Walsh, 2014).

The points-and-rewards system is consistent with the development of goal-oriented tasks in online games. These elements are able to navigate learners towards performance orientation as they are constantly emphasise direct goals like time and points earned. Learners earn rewards or points in the forms of trophies, badges and scores for every problem solved in the online games. These resulted in learners to become more engaged, motivated and develop self-determination to achieve certain goals. As supported by Chadyiwa and Mgutshini (2015), these games elements provide learners with fun learning experience whereby they will feel like they have to win challenges, complete the levels to obtain badges and prizes. Apparently, learners are excited to make multiple attempts and gain rewards.

Another valued element in online games is the prompt feedback. Such explicit and immediate feedback helps learners to think critically when assessing progress and reflect on their errors. The prompt feedback is a necessary element which contributes to the use of online games being meaningful (Nicholson, 2015), as it calls for learners' direct involvement in their own learning. Sullivan and Grey (2002) conclude that the use of online games in learning provides platforms for active learning. Learners learn by doing and not mere memorizing. When learners become active learners, they are able to become more productive and motivated in learning (Shaaruddin \& Mohamad, 2017).

Levels and leaderboard are significant in games application as it tracks learners' progress and records their achievement (Jia et al., 2017). Each level has different level of difficulties, which is an effective way to stimulate learners' intrinsic motivation through competition (Codish \& Ravid, 2015). Clearly defined progress gives learners a sense of achievement and inspires them to do what needs to be done to reach the next level. Leaderboard is a section where the scores and ranks are displayed. Learners can see how their achievements are being stacked against other fellow learners. This sparks healthy competition among learners which further motivates them to engage, practise and earn rewards.

Challenge is a basic element that makes up online games. It is a set of rules in online games that fuel learners to put effort in fulfilling tasks and compete. This element of challenge in online games is essential as it provides interactivity among learners and the game (Richter et al., 2015). When a game is not challenging, the interaction between game and the player could become meaningless. 
However, if it is too challenging, it could discourage learners and cause them to give up (Codish \& Ravid, 2015). Thus, there needs to be an appropriate amount of challenges for the online game to be an effective tool of language learning. Learners should be challenged on a subject matter that they have learned previously.

Teachers need to play their roles in ensuring that learners are prepared to learn using online games. Another role of the teachers is to give ample guidance when learners face difficulties (i.e. technical, instruction etc.). An adequate amount of challenge in online games learning provides space for learners to think, plan and actively engage in learning. Alsawaier (2018) wrote that the elements in online games (rewards, leader board, challenge and prompt feedback) are indispensable in the effort to ensure the effectiveness of online games in learning.

The use of online games in vocabulary learning has attained much attention, where different studies from many researchers globally have provided data that online games are able to gain attention and interest in vocabulary learning. The increasing rise of interest in online games in learning is due to its conceptualization as an enjoyable factor in language learning. Ashraf et al. (2014) also supported that online games create fun learning environment, especially for younger learners to be interested in learning process. Vocabulary building is a long process. Thus, engaging learners in fun, relaxing and motivating learning experience could ease learners to learn new words. Apparently, through such engagement, learners are more likely to reduce their learning apprehension level and arouse learners' interest in vocabulary learning. Barab et al.'s (2009) study confirm that online games could facilitate learning experience through the use of games elements, games thinking and games mechanics which makes learning more fun and rewarding in comparison to less attractive and passive traditional learning (Letchumanan et al., 2015). Fun and motivating learning environment raises learners' satisfaction in learning, thus, promotes high engagement among learners (Khalid \& Quick, 2016) and increase their level of English proficiency (Nejati, 2018; Alqahtani, 2016).

Yip and Kwan (2006) reported that the participants expressed a preference for the use of online games in vocabulary learning over face-to-face interaction as they welcome a higher degree of autonomy in their learning. The flexibility of online games provides opportunities for learners to become independent learners by allowing learners to progress at their own pace, choose the difficulty levels and provides multiple games formats that learners can choose from (Chiappe et al., 2013). Haddad (2016) also confirms that supporting learners with certain degree of autonomy in their learning is necessary to foster enhanced vocabulary in learning. Learners taking charge of their own learning involved taking responsibility (partial or total) for many stages of their learning process which traditionally belong to the teacher, such as making decision on learning goals, selecting learning methods and reviewing progress. Similarly, it is suggested that the ability to take charge of their learning progress suggests that learners have 
higher sense of self-efficacy and confidence in their own learning ability. Thus, learners who actively take charge of their learning are more intrinsically motivated than those who do not.

Online games potentials are not limited to learning a language component or skills as described in the lesson learning outcomes. In today's world, the integration of online games in vocabulary learning has given opportunities for learners to practice, learn and acquire multiple skills simultaneously. Online games in learning support the acquisition of $21^{\text {st }}$ century skills. Aside from gaining academic knowledge, educators now need to ensure that learners develop their 21st century skills. Chiappe et al. (2013) stated that online games have yield better performance in learners' problem-solving, critical thinking and collaboration skills. Besides learning the language component stated in the learning outcomes, there is a significant improvement in learners' problem-solving when they experimented with new strategies to complete the tasks given. Zirawaga et al. (2017) also provide findings that support the claim that online games "teach" other skills such as sportsmanship, creativity and peer collaboration. Instilling these qualities helps create individuals which can adapt to different challenges and situations. Besides, online games could increase opportunities for learners to create meaningful social connections with peers. As a result, their social, problem solving and creativity skills improve gradually as they communicate with other learners to compete or work collaboratively during the games. Yudintseva (2015) also has similar viewpoint, online games could strengthen learners' social relationship.

\section{The Challenges of Integrating Online Games in Language Learning}

Generally, there are three major challenges due to the integration of online games in language learning namely learners, educators and school administrators' readiness. Firstly, learners' readiness. One of the biggest challenges in implementing online games is learners' readiness in embracing the technology into learning. The use of a specific online game in a classroom may not be suitable to all learners. Some learners may find the features of online games as fascinating, while some others feel that the online games make their learning experience more difficult. Most of the time, learners who are not used to gamified classes have trouble adjusting to online games in learning (Bovermann et al., 2018). They often misunderstood the objectives of online games and feel that it is a waste of their time. Bovermann and his team members further revealed that $20 \%$ of the participants participating in their research expressed a rather dismissive attitude towards playing online games in learning. He suggested that participants could not relate to the benefits of online games in their learning. Instead, playing online games causes high level of anxiety and frustration when they could not reach their targeted achievement. Other negative effects that are often complained by the users are vision constraint and headache due to the long duration of time their eyes exposed to the bright rays on the monitor or handphone 
screen. Learners' negative view of online games may influence their acceptance and readiness to use online games in learning.

The growing interest for games-based learning in educational processes often highlights and lauds games' intrinsic educational value offered in gamified learning. However, there are limited past studies on the challenges that educators have to face in their effort to make online games a viable and useful tool in formal settings. Marklund and Taylor (2016) conducted a related study on this. Their findings explain the lack of educators' readiness in incorporating online games in learning. The findings highlight that online games are laborious and resource intensive to use, and that there are very few guidelines established to direct educators through the process of incorporating games into their working environments. Besides, some educators do not show a high level of readiness to use online games simply because they are technically unprepared. This could be due to their lack of knowledge and training on the varied online games products. Planning lessons with online games requires educators to have quite elaborate skill sets which involves technological know-how, gaming literacy and naturally a strong pedagogical foundation to be able to adapt different elements of games in learning (Talib et al., 2016). Thus, educators who are lacking in technical competency, opt to stay away from incorporating online games in their instructional practices as they may not be able to effectively guide and assist the learners in using them. On top of that, educators' readiness to adopt online games is also dependent on the suitability of the online games to be integrated with the subjects taught. Not all subjects are available via online games, thus, restrict educators from using online games as their class activities.

Thirdly, from the administrators' point of view, online games are often seen as a complementary practice to traditional classroom learning, and not as a primary tool for instruction (Mohamad et al., 2019). Al-Hajri et al. (2017) mentioned that the development of gamification environment raises significant challenge in terms of upgrading the required learning facilities. Administrators' support in funding to schools and education institutions is highly required to accommodate the demands in technological requirement and IT services. However, a few studies in the local Malaysia context have reported that poor infrastructure capabilities and insufficient resources are some common challenges faced by most of the local institutions (Nawaz \& Khan, 2012; Osman \& Bakar, 2012). This may be caused by the constant shift in technology and keeping up with the rate of technological change is costly. The lack of appropriate facilities such as computers, mobile phones and internet connectivity also could demotivate educators from adopting online games as class activities. Besides, the rather stretched academic timetable in primary schools in Malaysia could also lead to administrators' poor readiness to encourage online games to be integrated as classroom activities as they fear this would reduce the scheduled learners' learning time.

\section{Conclusion}

In this paper, a myriad of online games' potentials in learning have been ac- 
knowledged and discussed. Gamification in learning is known to be able to engage and motivate learners when adequately applied in learning. More specifically, this paper discussed relevant findings that online games could raise learners' learning satisfaction, foster autonomous learning as well as support the acquisition of $21^{\text {st }}$ century skills. Learners' satisfaction in language learning is more likely to increase with the appropriate use of pedagogical tools that are interesting and engaging learners in the learning process. Other than that, the autonomous learning element that is promoted through online games encourages learners to take charge of their own learning during class; as well as actively explore other resources in the target language beyond the classroom walls. Thus, developing autonomy in learners is as important as enhancing their vocabulary repertoire. Exposing learners to online games could assist them in acquiring $21^{\text {st }}$ century skills, besides the academic knowledge gained from the lesson. The $21^{\text {st }}$ century skills which are discussed in the paper are problem-solving, social and collaboration skills. These gamification elements have specific goals that would enable students to engage in meaningful learning processes and thus achieve intended learning outcomes (Landers et al. 2017; Talib et al., 2016). The elements of online games in vocabulary learning discussed in this paper are hoped to be able to encourage more educators to discover and integrate online games as their classroom intervention to enhance vocabulary learning. On the other hand, the challenges the three major stakeholders experience should not be overlooked. Learners, educators and administrators' levels of readiness affect the implementation of gamification in learning, specially to support the vision of Malaysia Ministry of Education (MOE) and enhance the Malaysia Standard-Based Curriculum English Syllabus where in Malaysia ESL learners' still struggle with vocabulary mastery (Ministry of Education, 2013).

\section{Acknowledgements}

This research was funded by the Faculty of Education's research niche (Instructional Technology) Universiti Kebangsaan Malaysia (UKM) under the project code GG-2019-021, GG-2019-013, GG-2019-018, GG 2020-015 and respectively. The authors would also like to express special thanks to all research team members, teachers and pupils, for their assistance and contribution in conducting this paper.

\section{Conflicts of Interest}

The authors declare no conflicts of interest regarding the publication of this paper.

\section{References}

Abrams, S. S., \& Walsh, S. (2014). Gamified Vocabulary: Online Resources and Enriched Language Learning. Journal of Adolescent and Adult Literacy, 58, 49-58.

https://doi.org/10.1002/jaal.315 
Afzal, N. (2019). A Study on Vocabulary-Learning Problems Encountered by BA English Majors at the University Level of Education. Arab World English Journal, 10, 81-98. https://doi.org/10.24093/awej/vol10no3.6

Al-Hajri, R., Al-Sharhan, S., \& Al-Hunaiyyan, A. (2017). Students' Perceptions of Mobile Learning: Case Study of Kuwait. International Journal of Educational and Pedagogical Sciences, 11, 371-374.

https://waset.org/publications/10006342/students-perceptions-of-mobile-learning-case -study-of-kuwait

Alqahtani, M. (2016). The Importance of Vocabulary in Language Learning and How to Be Taught. International Journal of Teaching and Education, 3, 21-34. https://doi.org/10.20472/TE.2015.3.3.002

Alsawaier, R. (2018). The Effect of Gamification on Motivation and Engagement. International Journal of Information and Learning Technology, 35, 56-79.

https://doi.org/10.1108/IJILT-02-2017-0009

Ashraf, H., Motlagh, F. G., \& Salami, M. (2014). The Impact of Online Games on Learning English Vocabulary by Iranian (Low-Intermediate) EFL Learners. Procedia-Social and Behavioral Sciences, 98, 286-291. https://doi.org/10.1016/j.sbspro.2014.03.418

Barab, S., Gresalfi, M., \& Arici, A. (2009). Why Educators Should Care about Games? Journal of the Department of Supervision and Curriculum Development, N.E.A. 6, 76-80.

https://www.worldcat.org/title/why-educators-should-care-about-games/oclc/4562576 10\&referer $=$ brief results

Bovermann, K., Weidlich, J., \& Bastiaens, T. (2018). Online Learning Readiness and Attitudes towards Gaming in Gamified Online Learning-A Mixed Methods Case Study. International Journal of Educational Technology in Higher Education, 15, Article No. 27. https://doi.org/10.1186/s41239-018-0107-0

Chadyiwa, M., \& Mgutshini, T. (2015). Using Mobile Handheld Devices as Tools of Learning and Teaching for Student EHPS: A Blessing or a Curse. International Journal of Humanities, Arts and Social Sciences, 1, 85-91.

Chapman, J. R., \& Rich, P. J. (2018). Does Educational Gamification Improve Students' Motivation? If So, Which Games Elements Work Best? Journal of Education for Business, 93, 314-321. https://doi.org/10.1080/08832323.2018.1490687

Chiappe, D., Conger, M., Liao, J., Caldwell, J. L., \& Vu, K. P. L. (2013). Improving Multi-Tasking Ability through Action Videogames. Applied Ergonomics, 44, 278-284. https://doi.org/10.1016/j.apergo.2012.08.002

Codish, D., \& Ravid, G. (2015). Detecting Playfulness in Educational Gamification through Behavior Patterns. IBM Journal of Research and Development, 59, 6:1-6:14. https://doi.org/10.1147/JRD.2015.2459651

D’Silva, V. (2019). Challenges in Students' Mastery of English. News Strait Times. https://www.nst.com.my/news/nation/2019/10/531486/challenges-students-mastery-en glish

Darejeh, A., \& Salim, S. S. (2016). Gamification Solutions to Enhance Software User Engagement Systematic Review. International Journal of Human-Computer Interaction, 32, 613-642. https://doi.org/10.1080/10447318.2016.1183330

Derakhshan, A., \& Khatir, E. D. (2015). The Effects of Using Games on English Vocabulary Learning. Journal of Applied Linguistics and Language Research, 2, 39-47.

Deterding, S., Dixon, D., Khaled, R., \& Nacke, L. (2011). Gamification: Toward a Definition. CHI 2011 Gamification Workshop Proceedings, January 2011, 12-15.

https://www.researchgate.net/publication/273947177 Gamification Toward a definiti 
Figueroa-Flores, J. F. (2015). Using Gamification to Enhance Second Language Learning. Digital Education Review, 27, 32-54.

Haddad, R. H. (2016). Developing Learner Autonomy in Vocabulary Learning in Classroom: How and Why Can It Be Fostered? Procedia-Social and Behavioral Sciences, 2, 784-791. https://doi.org/10.1016/j.sbspro.2016.10.106

Hamari, J., \& Sarsa, H. (2014). Does Gamification Work? A Literature Review of Empirical Studies on Gamification. 47th Hawaii International Conference on System Sciences, Waikoloa, 6-9 January 2014. https://doi.org/10.1109/HICSS.2014.377

Jia, Y., Liu, Y., Yu, X., \& Voida, S. (2017). Designing Leader Boards for Gamification: Perceived Differences Based on User Ranking, Application Domain, and Personality Traits. Conference on Human Factors in Computing Systems Proceedings, May 2017, 1949-1960. https://doi.org/10.1145/3025453.3025826

Kessler, G. (2018). Technology and the Future of Language Teaching. Foreign Language Annals, 51, 205-218. https://doi.org/10.1111/flan.12318

Khalid, N. M., \& Quick, D. (2016). Teaching Presence Influencing Online Students' Course Satisfaction at an Institution of Higher Education. International Education Studies, 9, 62. https://doi.org/10.5539/ies.v9n3p62

Landers, R. N., Armstrong, M. B., \& Collmus, A. B. (2017). How to Use Game Elements to Enhance Learning: Applications of the Theory of Gamified Learning. In M. Ma, A. Oikonomou, \& L. C. Jain (Eds.), Serious Games and Edutainment Applications (Vol. 2, pp. 457-483). Surrey: Springer. https://doi.org/10.1007/978-3-319-51645-5 21

Lateh, N. H. M., Shamsudin, S., \& Abdul Raof, A. H. (2018). Receptive Vocabulary Levels of Malaysian University Students. LSP International Journal, 5, 105-113. https://doi.org/10.11113/lspi.v5n1.68

Letchumanan, K., Tan, B. H., Paramasivam, S., Sabariah, M. R., \& Muthusamy, P. (2015). Incidental Learning of Vocabulary through Computer-Based and Paper-Based Games by Secondary School ESL Learners. Pertanika Journal of Social Science and Humanities, 23, 725-740.

https://www.researchgate.net/publication/280939559 Incidental Learning of Vocabul ary through Computer-Based and Paper-Based Games by Secondary School ESL Learners

Marklund, B. B., \& Alkind Taylor, A. (2016). Educational Games in Practice: The Challenges Involved in Conducting a Games-Based Curriculum. The Electronic Journal of E-Learning, 14, 122-135.

Ministry of Education (2013). Malaysia Education Blueprint 2013-2015: Preschool to Post Secondary Education. Putrajaya: MOE.

Mohamad, M., Arif, F. K. M., Alias, B. S., \& Yunus, M. M. (2020). Online Games-Based Formative Assessment: Distant Learners Post Graduate Students' Challenges towards Quizizz. International Journal of Scientific and Technology Research, 9, 994-1000.

Mohammad, S. N. M., Sazali, N. S. S., \& Salleh, M. A. M. (2018). Gamification Approach in Education to Increase Learning Engagement. International Journal of Humanities, Arts and Social Sciences, 4, 22-32. https://doi.org/10.20469/ijhss.4.10003-1

Nasir, M. K. M., Surat, S., Maat, S. M., Abd Karim, A., \& Daud, Md. Y. (2018). Confirmatory Factor Analysis on the Sub-Construct of Teaching Presence's in the Community of Inquiry. Creative Education, 9, 2245-2253.

https://doi.org/10.4236/ce.2018.914165

Nasir, M. K. N., Mansor, M. Z., \& Rahman, M. J. A. (2018). Measuring Malaysian Online 
University Student Social Presence in Online Course Offered. Journal of Advanced Research in Dynamical and Control Systems, 12, 1442-1446.

Nawaz, A., \& Zubair Khan, M. (2012). Issues of Technical Support for e-Learning Systems in Higher Education Institutions. International Journal of Modern Education and Computer Science, 4, 38-44. https://doi.org/10.5815/ijmecs.2012.02.06

Nejati, E., Jahangiri, A., \& Salehi, M. R. (2018). The Effect of Using Computer-Assisted Language Learning (CALL) on Iranian EFL Learners' Vocabulary Learning: An Experimental Study. Cypriot Journal of Educational Science, 13, 351-362. https://doi.org/10.18844/cjes.v13i2.752

Nicholson, S. (2015). A Recipe for Meaningful Gamification. In Gamification in Education and Business (pp. 1-20). Berlin: Springer. https://doi.org/10.1007/978-3-319-10208-5 1

Osman, K., \& Bakar, N. A. (2012). Educational Computer Games for Malaysian Classrooms: Issues and Challenges. Asian Social Science, 8, 75-84. https://doi.org/10.5539/ass.v8n11p75

Richter, G., Raban, D. R., \& Rafaeli, S. (2015). Studying Gamification: The Effect of Rewards and Incentives on Motivation. In T. Reiners, \& L. C. Wood (Eds.), Gamification in Education and Business (pp. 21-45). Berlin: Springer International Publishing. https://doi.org/10.1007/978-3-319-10208-5 2

Shaaruddin, J., \& Mohamad, M. (2017). Identifying the Effectiveness of Active Learning Strategies and Benefits in Curriculum and Pedagogy Course for Undergraduate TESL Students. Creative Education, 8, 2312-2324. https://doi.org/10.4236/ce.2017.814158

Sullivan, E. J., \& Gray, G. (2002). Efficacy of Computer Games on Language Learning Blanka. Journal of Professional Nursing, 18, 245-246. https://doi.org/10.1053/jpnu.2002.129225

Talib, N., Yassin, S. F. M., \& Nasir, M. K. M. (2016). Assessment Study Computer Programming Based on Creative Problem-Solving Approach of "Grounded Theory". Journal of Advanced Research in Social and Behavioural Sciences, 5, 25-38.

Ting, C. W., \& Kee, L. L. (2019). Using Vocabulary Journals to Improve Vocabulary Learning among Primary School Pupils in Malaysia. Journal of English Education (JEE), 4, 108-120. https://doi.org/10.31327/jee.v4i2.1111

Wang, F., \& Yamat, H. (2019). Identifying English Vocabulary Levels of Malaysia Year 5 Primary School Students. International Journal of Academic Research in Business and Social Sciences, 9, 62-76.

Yip, F. W. M., \& Kwan, A. C. M. (2006). Online Vocabulary Games as a Tool for Teaching and Learning English Vocabulary. Educational Media International, 43, 233-249. https://doi.org/10.1080/09523980600641445

Yudintseva, A. (2015). Games-Enhanced Second Language Vocabulary Acquisition Strategies: A Systematic Review. Open Journal of Social Sciences, 3, 101-109. https://doi.org/10.4236/jss.2015.310015

Zainuddin, Z., Shujahat, M., Haruna, H., \& Chu, S. K. W. (2020). The Role of Gamified e-Quizzes on Student Learning and Engagement: An Interactive Gamification Solution for a Formative Assessment System. Computers and Education, 145, Article ID: 103729. https://doi.org/10.1016/j.compedu.2019.103729

Zirawaga, V., Olusanya, A., \& Maduki, T. (2017). Gaming in Education: Using Games a Support Tool to Teach History. Journal of Education and Practice, 8, 55-64.

https://files.eric.ed.gov/fulltext/EJ1143830.pdf 